NOTE

\title{
First record of Huffmanela schouteni (Nematoda: Trichosomoididae), a histozoic parasite of flyingfishes, in Europe
}

\author{
František Moravec $^{1, *}$, Fulvio Garibaldi $^{2}$ \\ ${ }^{1}$ Institute of Parasitology, Academy of Sciences of the Czech Republic, Branišovská 31, 37005 České Budějovice, \\ Czech Republic \\ ${ }^{2}$ Dipartimento per lo Studio del Territorio e delle sue Risorse (DIP.TE.RIS), Laboratori di Biologia Marina ed Ecologia Animale, \\ Università di Genova, Viale Benedetto XV 3, 16132 Genova, Italy
}

\begin{abstract}
Examination of 3 specimens of the Mediterranean flyingfish Cheilopogon heterurus (Rafinesque) from the Ligurian Sea, Italy, revealed the presence of numerous, dark-shelled trichinelloid eggs (69 to $75 \times 30$ to $33 \mu \mathrm{m}$ ) inside the innermost layer of the swimbladder, mostly located in clumps arranged in a distinct pattern. These were identified as Huffmanela schouteni Moravec et Campbell, 1991, a species known so far as eggs in flyingfishes and in the stools of humans in Curaçao. This is the first finding of this parasite in Europe and $C$. heterurus represents a new host record.
\end{abstract}

KEY WORDS: Parasitic nematode - Tissue parasite Huffmanela - Marine fish Cheilopogon · Ligurian Sea $\cdot$ Italy

Resale or republication not permitted without written consent of the publisher

\section{INTRODUCTION}

The genus Huffmanela Moravec, 1987 (Trichinelloidea: Trichosomoididae) represents a group of poorly known species of histozoic nematodes parasitic in various tissues of elasmobranchs and bony fishes. At present it comprises 8 species, 7 of which are known only by their characteristic eggs (Moravec 2001). The eggs usually occur in masses in the host's tissues, frequently as conspicuous 'black spots' in the flesh or other fish organs. Sometimes these eggs are recorded from the stools of humans after consumption of infected fishes. Although these parasites are unimportant from the viewpoint of public health, the presence of their eggs in masses in fish flesh may cause commercial problems. Nothing is known about the life cycles of these parasites.

We examined 3 specimens of the flyingfish Cheilopogon heterurus (Rafinesque) (Beloniformes: Exocoeti- dae) originating from the western Ligurian Sea, near Sanremo, Italy, on 3 occasions during the years 2000 and 2001.

Of these, 2 individuals - a mature male $(34.9 \mathrm{~cm}$ total length, TL) caught by artisanal purse seine in July 2000 and a mature female $(37.5 \mathrm{~cm}$ TL) derived from the stomach contents of a dolphin fish, Coryphaena hippurus (Linnaeus), in June 2001 - harboured very numerous, dark-shelled trichinelloid eggs inside the innermost layer of the swimbladder, which were identified as Huffmanela schouteni Moravec et Campbell, 1991. The third fish, an immature male $(17.6 \mathrm{~cm} \mathrm{TL})$ caught by purse seine in August 2001, had no sign of infection.

The fully developed eggs of the trichinelloid recovered from Cheilopogon heterurus (Fig. 1) are darkbrown, elongate-oval, with a 2-layered shell. The inner layer is thin and light in colour; the outer layer is thick, with a smooth surface, and is dark in colour, with light- 


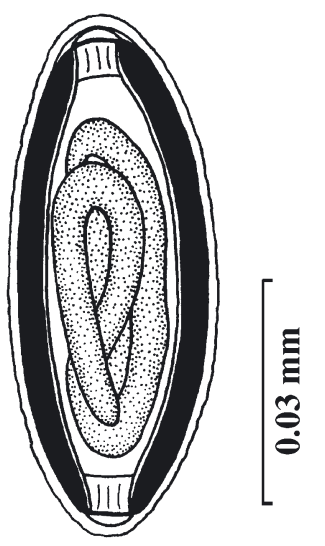

Fig. 1. Huffmanela schouteni Moravec et Campbell, 1991. Fully developed egg of the parasite from the swimbladder of Cheilopogon heterurus

coloured polar plugs protruding through it. The egg contains a larva. The whole egg, including polar plugs, is covered by a thin transparent layer (envelope) with a very fine superficial sculpture. The size of the eggs is 69 to $75 \times 30$ to $33 \mu \mathrm{m}$, with a width:length ratio of $1: 2.3$ to 2.5 ; other measurements correspond to the original species description.

There was a distinct pattern in the grouping of eggs in the host tissue, resulting in a striped or barred pattern, probably caused by the female moving while laying eggs (Fig. 2). Sometimes, single eggs or groups of a few eggs were embedded in thin-walled capsules produced by the host tissue, and/or some eggs were even decomposing as a result of the host's tissue reaction.

Huffmanela schouteni was first described by Moravec \& Campbell (1991) from eggs allegedly found in the serosa cover of the intestine, abdominal cavity and liver of 2 species of flyingfishes, Hirundichthys affinis (Günther) and Cheilopogon cyanopterus (Valenciennes) (both Exocoetidae), from Curaçao in the Caribbean region. These eggs (designated as 'C-eggs') were first detected in the stools of 6 patients in Curaçao by Schouten et al. (1968), who discovered the source of the eggs (fish-soup prepared from flyingfishes bought at the local market), and recorded heavy infections of the eggs in these 2 flyingfish species (see also SurielSmeets \& Schouten 1972). H. schouteni has not been recorded since.

The morphology of the eggs in the present study fully agrees with that of Huffmanela schouteni. The host, Cheilopogon heterurus, is closely related to the type host C. cyanopterus, and therefore there is no doubt about the specific identity of the eggs. Although the location (swimbladder) of the nematode eggs in the host in the present study differs from that originally (abdominal cavity and liver) reported for H. schouteni, it is highly probable that the data given by Moravec \& Campbell (1991) were not accurate in this respect; the swimbladder location of Huffmanela spp. eggs is characteristic also for $H$. huffmani Moravec, 1987 and $H$. mexicana Moravec et Fajer-Avila, 2000.

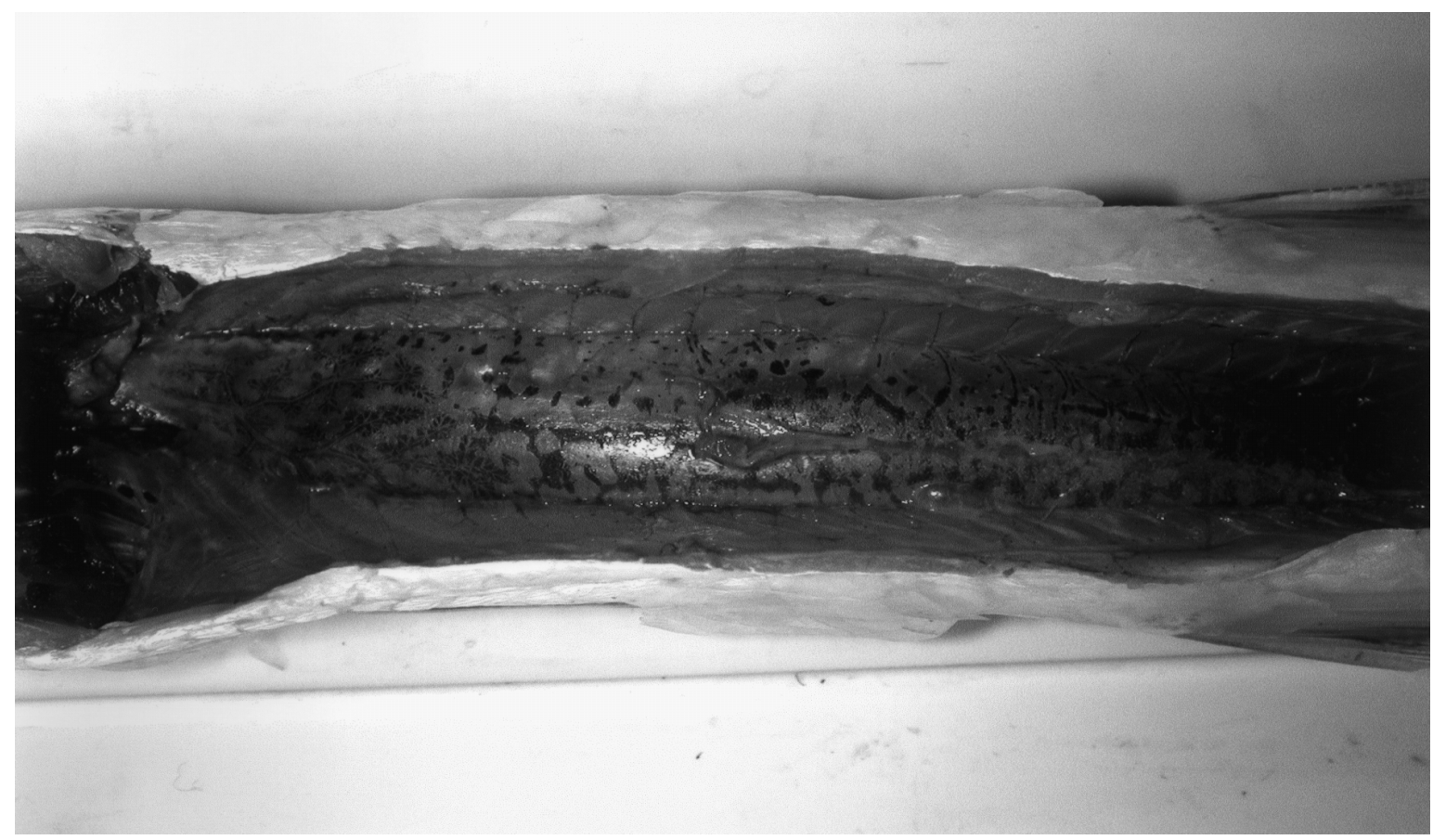

Fig. 2. Cheilopogon heterurus. Swimbladder of adult male containing eggs of Huffmanela schouteni 
The occurrence of Huffmanela schouteni in 2 very widely separated geographical regions (Caribbean and Mediterranean) is evidently associated with the distribution areas of their pelagic hosts.

Hirundichthys affinis and Cheilopogon cyanopterus both occur in the tropical and subtropical zone in the western and eastern Atlantic, from the Caribbean to the Gulf of Guinea, Gabon, and South Africa (Oxenford et al. 1995, Froese \& Pauly: available at www. fishbase.org). On the other hand, $C$. heterurus has been recorded in the western Atlantic (Khokiattiwong et al. 2000) and is also regularly present in the northeastern Atlantic area, including the western Mediterranean Sea (Parin 1986, Froese \& Pauly: www.fishbase. org), where, however, it is not targeted by any specifically addressed fishing gear or fishing technique, and is rarely recorded by the commercial fishing industry, as it is not considered a commercially marketable product.

Its biology and spatial and temporal distribution in the Mediterranean Sea are poorly known, and no precise data are available in the literature. Strictly inhabiting epipelagic waters, it is a known planktonic feeder. Reproduction occurs during the summer months, when characteristic egg masses are found attached to floating objects.

Taking into account the particular habitat and limited ecological niche occupied by species of the family Exocoetidae, it is probable that the infection route is the same for all members of the family, and is perhaps linked to the migratory pattern of Cheilopogon heterurus from the Mediterranean to the Atlantic.

To date, Huffmanela schouteni is the second Huffmanela species reported in fishes from European waters; the only other species is $H$. paronai Moravec et Garibaldi, 2000 described from the skin of the swordfish Xiphias gladius Linnaeus from the Ligurian Sea in Italy (Moravec \& Garibaldi 2000). Eggs of an unidentified species of Huffmanela were also recorded from the stool of a child in Spain (Gállego et al. 1993).

Editorial responsibility: Wolfgang Körting,

Hannover, Germany
The finding of $H$. schouteni in Cheilopogon heterurus represents a new host record.

Acknowledgements. The authors thank Mrs. I. Husáková, Institute of Parasitology, ASCR, České Budějovice, Czech Republic, for her technical assistance with the preparation of Fig. 1. This paper was partly supported by grant no. A6022201 from the Grant Agency of the Academy of Sciences of the Czech Republic.

\section{LITERATURE CITED}

Gállego J, Riera C, Portús M (1993) Huffmanela sp. eggs (Nematoda: Trichosomoididae), as a human spurious parasite in a child from Barcelona (Spain). Folia Parasitol (České Budějovice) 40:208-210

Khokiattiwong S, Mahon R, Hunte W (2000) Seasonal abundance and reproduction of the fourwing flyingfish, Hirundichthys affinis, off Barbados. Environ Biol Fish 59: $43-60$

Moravec F (2001) Trichinelloid nematodes parasitic in coldblooded vertebrates. Academia, Prague

Moravec F, Campbell BG (1991) A new Huffmanela species, H. schouteni sp. n. (Nematoda: Trichosomoididae), from flying fishes in Curaçao. Folia Parasitol (České Budějovice) 38:29-32

Moravec F, Garibaldi F (2000) A new Huffmanela species, $H$. paronai sp. n. (Nematoda: Trichosomoididae), from the skin of swordfish Xiphias gladius in Italy. Folia Parasitol (České Budějovice) 47:309-313

Oxenford HA, Mahon R, Hunte W (1995) Distribution and relative abundance of flyingfish (Exocoetidae) in the Eastern Carribean. I. Adults. Mar Ecol Prog Ser 117:11-23

Parin NV (1986) Exocoetidae. In: Whitehead PJP, Bauchot ML, Hureau JC, Nielsen J, Tortonese E (eds) Fishes of the north-eastern Atlantic and the Mediterranean, Vol 2. UNESCO, Paris, p 612-619

Schouten H, Suriel-Smeets RM, Kibbelaar MA (1968) The simultaneous occurrence of ova resembling Dicrocoelium dendriticum or Capillaria hepatica in the stools of inhabitants of Curaçao. Trop Geogr Med 20:271-275

Suriel-Smeets RM, Schouten H (1972) The simultaneous occurrence of ova resembling Dicrocoelium dendriticum and Capillaria hepatica in the stools of inhabitants of Curaçao. II. Identification of the D-trematode: Didymozoon sp. Trop Geogr Med 24:192-193

Submitted: June 2, 2003; Accepted: August 8, 2003

Proofs received from author(s): October 20, 2003 